\title{
Potential Importance of Molybdenum Priming to Metabolism and Nutritive Value of Canavalia spp. Sprouts
}

\author{
Mohammad K. Okla ${ }^{1, *,+}$, Nosheen Akhtar ${ }^{2, *}++^{\mathbb{D}}$, Saud A. Alamri ${ }^{1} \mathbb{D}$, Salem Mesfir Al-Qahtani ${ }^{3} \mathbb{D}$, \\ Ahmed Ismail ${ }^{4}$, Zahid Khurshid Abbas ${ }^{5}$, Abdullah A. AL-Ghamdi ${ }^{1}$, Ahmad A. Qahtan ${ }^{1}$, Walid H. Soufan ${ }^{6}$, \\ Ibrahim A. Alaraidh ${ }^{1}$, Samy Selim ${ }^{7}$ (D) and Hamada AbdElgawad ${ }^{8,9}$
}

1 Botany and Microbiology Department, College of Science, King Saud University, Riyadh 11451, Saudi Arabia; saualamri@ksu.edu.sa (S.A.A.); abdaalghamdi@ksu.edu.sa (A.A.A.-G.); aqahtan@ksu.edu.sa (A.A.Q.); ialaraidh@ksu.edu.sa (I.A.A.)

2 Department of Biological Sciences, National University of Medical Sciences, Rawalpindi 46000, Pakistan

3 Biology Department, University College of Taymma, Tabuk University, Tabuk 71411, Saudi Arabia; salghtani@ut.edu.sa

4 Pharmacognosy Department, Faculty of Pharmacy, Fayoum University, Fayoum 63514, Egypt; Ais03@fayoum.edu.eg

5 Department of Biology, Faculty of Science, University of Tabuk, Tabuk 71491, Saudi Arabia; Znourabbas@ut.edu.sa

6 Department of Plant Production, Faculty of Food and Agriculture Sciences, King Saud University, Riyadh 11451, Saudi Arabia; waoufan@ksu.edu.sa

Citation: Okla, M.K.; Akhtar, N.; Alamri, S.A.; Al-Qahtani, S.M.; Ismail, A.; Abbas, Z.K.; AL-Ghamdi, A.A.; Qahtan, A.A.; Soufan, W.H.; Alaraidh, I.A.; et al. Potential Importance of Molybdenum Priming to Metabolism and Nutritive Value of Canavalia spp. Sprouts. Plants 2021, 10, 2387. https://doi.org/10.3390/plants 10112387

Academic Editors: Beatrice Falcinelli and Angelica Galieni

Received: 22 September 2021

Accepted: 26 October 2021

Published: 5 November 2021

Publisher's Note: MDPI stays neutral with regard to jurisdictional claims in published maps and institutional affiliations.

Copyright: (c) 2021 by the authors. Licensee MDPI, Basel, Switzerland. This article is an open access article distributed under the terms and conditions of the Creative Commons Attribution (CC BY) license (https:/ / creativecommons.org/licenses/by/ $4.0 /)$.
7 Department of Clinical Laboratory Sciences, College of Applied Medical Sciences, Jouf University, Sakaka 72388, Saudi Arabia; sabdulsalam@ju.edu.sa

8 Integrated Molecular Plant Physiology Research, Department of Biology, University of Antwerp, 2020 Antwerpen, Belgium; hamada.abdelgawad@uantwerpen.be

9 Botany and Microbiology Department, Faculty of Science, Beni-Suef University, Beni-Suef 62511, Egypt

* Correspondence: malokla@ksu.edu.sa (M.K.O.); nosheenakhtar@numspak.edu.pk (N.A.)

$+\quad$ These authors contributed equally and share first authorship.

Abstract: Molybdenum ions (Mo) can improve plants' nutritional value primarily by enhancing nitrogenous metabolism. In this study, the comparative effects of seed priming using Mo were evaluated among sproutings of Canavalia species/cultivars, including Canavalia ensiformis var. gladiata (CA1), Canavalia ensiformis var. truncata Ricker (CA2), and Canavalia gladiata var. alba Hisauc (CA3). Mo impacts on growth, metabolism (e.g., nitrogen and phenolic metabolism, pigment and total nutrient profiles), and biological activities were assayed. Principal component analysis (PCA) was used to correlate Mo-mediated impacts. The results showed that Mo induced photosynthetic pigments that resulted in an improvement in growth and increased biomass. The $\mathrm{N}$ content was increased 0.3-fold in CA3 and 0.2-fold in CA1 and CA2. Enhanced nitrogen metabolism by Mo provided the precursors for amino acids, protein, and lipid biosynthesis. At the secondary metabolic level, phenolic metabolism-related precursors and enzyme activities were also differentially increased in Canavalia species/cultivars. The observed increase in metabolism resulted in the enhancement of the antioxidant (2,2-diphenyl-1-picryl-hydrazyl-hydrate (DPPH) free radical scavenging, 2,2-azinobis(3-ethylbenzothiazoline-6-sulfonic acid) (ABTS), ferric reducing antioxidant power (FRAP)) and antidiabetic potential (Glycemic index (GI) and inhibition activity of $\alpha$-amylase, and $\alpha$-glucosidase) of species. The antioxidant activity increased $20 \%$ in CA3, $14 \%$ in CA1, and $8 \%$ in CA2. Furthermore, PCA showed significant variations not only between Mo-treated and untreated samples but also among Canavalia species. Overall, this study indicated that the sprouts of Canavalia species have tremendous potential for commercial usage due to their high nutritive value, which can be enhanced further with Mo treatment to accomplish the demand for nutritious feed.

Keywords: Canavalia; molybdenum; seed priming; nitrogen assimilation 


\section{Introduction}

Developing countries are facing an increasing demand for protein and other nutrientrich foods. In this context, legumes can contribute as the most valuable source of nutrients and provide high-quality dietary proteins [1]. Legume plants have desirable characteristics such as an abundance of carbohydrates, the ability to lower serum cholesterol, high fiber, a high concentration of polyunsaturated fatty acids, and long shelf life. In addition to B complex vitamins such as folate, thiamin, and riboflavin, minerals, and fiber, legumes are also major sources of proteins and calories [2]. Furthermore, it is evidenced that sprouts are the richest source of proteins and other compounds of nutritional value compared to un-sprouted plants [3]. Moreover, sprouts have also been associated with a variety of biologically active constituents with potential health benefits. During germination, metabolic enzymes are activated, which can lead to the release of some amino acids and peptides, and the synthesis or use of them can form new proteins. As a consequence, the nutritional and medicinal value might be enhanced by sprouting in legumes. Research has to be geared to exploit the sprouting of legumes and enhance their nutrition values to meet the nutritional requirements of the increasing population.

The genus of Canavalia is considered the third largest family among flowering plants [1]. It comprises approximately 50 species of tropical vines widely distributed in tropical and subtropical regions all over the world [4]. This genus was used traditionally as a food due to its nutritional significance. Sridhar and Seena envisaged a comparative account of nutritional and functional properties of Canavalia species [5]. Canavalia gladiata and Canavalia ensiformis are the common legume species having the potential to be a rich protein source, like edible legumes [5]. Pharmacological effects of Canavalia gladiata are reported for cancer [6], allergies [7], antioxidants [8], and inflammation [9]. Canavalia gladiata in complex with Arctium lappa extract is proposed to develop as a functional food for stimulating immunity [10]. Similarly, the seeds of Canavalia ensiformis are a source of proteins with biotechnological importance including ureases [11] and proteases [12]. Processed seeds of Canavalia ensiformis are reported for enhanced antioxidant activity [13]. Hence, Canavalia species are of high medical importance, and with proper seed priming with micronutrients and using other treatments nutritional and pharmacological values can be enhanced.

Micronutrients are vital for plant growth because they act as a cofactor of the enzyme, take part in redox reactions, and have several other important functions [14]. Furthermore, despite addition to the soil, micronutrient application using seeds improves the stand formation, advances phenological events, and increases yield and micronutrient grain contents [14]. Like different micronutrients, molybdenum (Mo) is very vital and essential for plants' physiological functions. In plants with inadequate Mo, nitrates accrue in leaves, which then do not assimilate into proteins. In legumes, Mo serves an additional function: to help root nodule bacteria to fix atmospheric nitrogen $(\mathrm{N})$. Studies revealed that the application of Mo in beans, via seeds, increases the mass of the nodule [15]; moreover, its foliar spray increases nodule formation, nitrogen contents, the grain number, the grain mass, and overall productivity [16]. The enhanced benefits may be attributed to the acceleration of $\mathrm{N}$ absorption and assimilation processes via BNF (biological nitrogen fixation) [14]. Mo is a crucial element for more than 40 enzymes, four of which have been found in plants, including nitrate reductase (NR) and nitrogenase synthesis [17,18]. Thus, plants receiving increased Mo will have increased $\mathrm{N}$ productivity levels based on the higher activities of the abovementioned enzymes. Mo bound to a unique pterin compound, named Mo cofactor, binds to diverse apoproteins and aids in anchoring the Mo center at the correct position within the holo-enzyme for its correct interaction with other components of the electron transport chain [17]. Thus, Mo supply can strengthen plant metabolism at different growth stages through an improved enzymatic and non-enzymatic antioxidant defense system and also enhance other pharmacological properties [19]. Moreover, Mo is also an essential mineral for the human body as it is part of important metabolic enzymes such as xanthine oxidase sulfite oxidase, aldehyde oxidase, and mitochondrial amidoxime reducing component. 
With this background, we hypothesized that Mo application can enhance the nutritional and pharmacological value of Canavalia species by improving their $\mathrm{N}$ content and resulting in primary and secondary metabolite production. Thus, the present study aimed to evaluate the impact of Mo seed priming on three Canavalia species/cultivar sprouts. To the best of our knowledge, no study has been conducted to assess the influence of Mo seed priming on Canavalia ensiformis var. gladiata, Canavalia ensiformis var. truncata Ricker, and Canavalia gladiata var. alba Hisauc. Herein, we evaluated the impacts of Mo treatment on growth, $\mathrm{N}$ content, and phenolic metabolism as well as on the concentrations of several phytochemical compounds. We further examined the role of Mo in the enhancement of pharmacological properties of Canavalia species. Overall, our study contributed to an understanding of the biochemical basis of Mo that induces high growth and tissue quality of different Canavalia species/cultivars.

\section{Results}

\subsection{Biomass and Pigment Content}

To quantify the biomass of the molybdenum (Mo)-treated cultivar/species of Canavalia, the validated method was employed. An increase in fresh weight was observed in all the sproutings of the three studied species/cultivars, as shown in Figure 1A. Significant differences were observed among Mo-treated and non-treated groups. The difference was almost negligible within the sproutings of different species. Next, different types of chlorophylls such as chlorophyll $a$, chlorophyll $b$, and chlorophyll ab were quantified in both Mo-treated and untreated plants. The results indicated that exogenous Mo application increased chlorophyll content in the leaves of all the studied Canavalia species, as shown in Figure 1B. In untreated sprouts of Canavalia ensiformis var. gladiata (CA1), Canavalia ensiformis var. truncata Ricker (CA2), and Canavalia gladiata var. alba Hisauc (CA3), chlorophyll ab was present in a higher amount as compared to chlorophyll a and b, which was significantly increased after seed priming with Mo, as shown in Figure 1B. Further, the impact of Mo on the production of carotenoids was studied. Concentrations of $\alpha$-carotene, $\beta$-carotene, and lycopene were quantified. A significant increase in the production of T-carotene and B-carotene was observed in all the Mo-treated species/cultivars, while the concentration of lycopene remained the same, as shown in Figure 1B.

\subsection{Nutritional Value}

The variations in the concentration of nutrients (lipids, proteins, and fibers) and phytochemicals (alkaloids, flavonoids, saponins, and glycosides) were quantified in both Mo-exposed and unexposed seeds of Canavalia. The quantity of total lipids was significantly increased in CA1, a non-significant change was observed in CA2, while a decrease was recorded in CA3. Furthermore, a significant increase in fiber content was recorded in CA1, a decrease was found in CA3, while there was no change in the fiber content of CA2. Upward trends in total proteins, flavonoids, saponins, and glycosides were noticed (Table 1).

\subsection{Nitrogen and Amino Acid Metabolism}

The outcome of Mo treatment on the nitrogen $(\mathrm{N})$ content was studied in Canavalia species. The results showed a slight increase in $\mathrm{N}$ production in the sproutings of three species, as shown in Figure 2A. Moreover, the quantification of nitrogen reductase (NR) activity showed its increase in CA3 and decrease in CA1 and CA2 in Mo-treated plants, as shown in Figure 2B. Next, we studied the effect of Mo on two pathways of glutamate synthesis, i.e., glutamate-dehydrogenase (GDH) and glutamine synthetase (GS)/glutamate synthase (GOGAT) pathways. The activities of GDH, GOGAT, and GS were measured (Figure 2C-E). The results showed an increase in GDH and GOGAT activity in the three species. The rise in GDH activity was significant in CA3, while it was non-significant in other species. Inversely, GS activity was decreased after Mo treatment and the differences were highly significant in the three species/cultivars. Further, the impact of Mo treatment 
on dihydrodipicolinate synthase (DHDPS) and cystathionine $\gamma$ - synthase (CGS) activity was explored. The experiment showed that the activity of DHDPS significantly increased in CA3 and non-significantly in CA1 and CA2 (Figure 2F). Moreover, a notable increase in the activity of CGS was measured in sprouts of CA3 (Figure 2G). Furthermore, amino acids, i.e., asparagine, glutamine, glycine, glutamic acid, isoleucine, arginine, tyrosine, lysine, serine, alanine, proline, histidine, leucine, isoleucine, valine, cystine, threonine, tryptophan, and methionine, were quantified in Mo-treated Canavalia species and data were compared to untreated controls. The changes in each amino acid content due to Mo exposure are shown in Table 2. Overall, an increase in amino acid production was detected in the three species. The quantity of cystine, isoleucine, leucine, glycine, alanine, and proline was increased significantly in CA1; asparagine, glutamine, glutamic acid, alanine, proline, cystine, and lysine were enhanced in CA2; and asparagine, glutamine, glycine, histidine, methionine, cystine, isoleucine, tyrosine, lysine, threonine, and tryptophan were enhanced in CA3. Variable trends were noticed among different sprouts. The concentrations of alanine and proline were found to be improved in CA1 and CA2, while they declined in CA3. Levels of histidine, arginine, valine, threonine, and tryptophan increased in CA1 and CA3, whereas they decreased in CA2. Leucine was increased in CA1 and reduced in CA3 and CA2. All results are enumerated in Table 2.
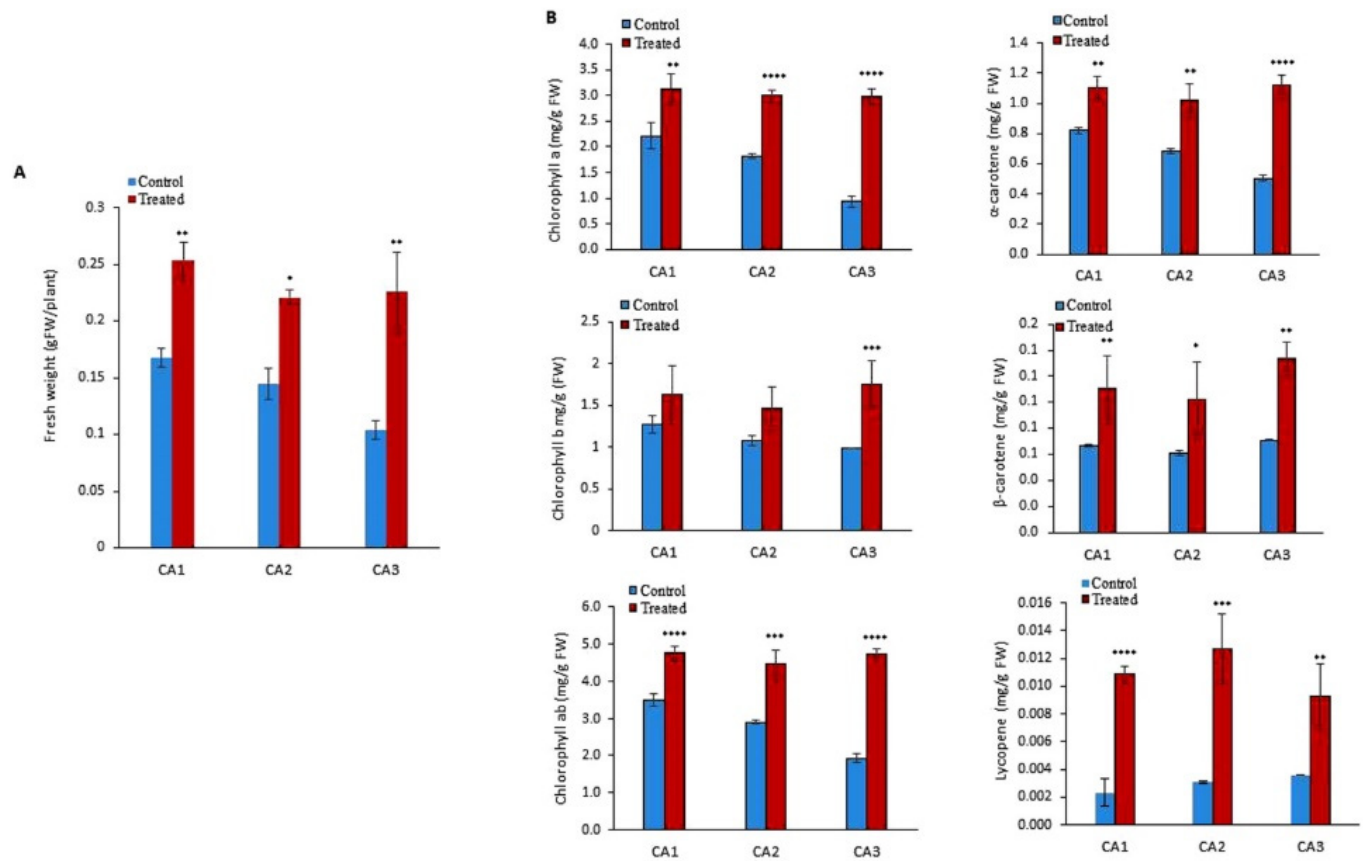

Figure 1. Impacts of molybdenum (Mo) seed priming on different Canavalia species. (A): Total biomass (gFW). (B): Chlorophyll a, b, and ab content, $\alpha$-carotene content, $\beta$-carotene content, and lycopene content were measured and expressed as $\mathrm{mg} / \mathrm{gFW}$. Control; without treatment, Treated; Mo treatment. CA1; Canavalia ensiformis var. gladiata, CA2; Canavalia ensiformis var. truncata Ricker, CA3; Canavalia gladiata var. alba Hisauc. $\alpha$-carotene, or $\beta$-carotene, Beta-carotene. The bars above mean indicate \pm standard deviation (S.D) of three independent replicates $(n=3)$. Asterisks ${ }^{*}$ ) show the level of significance ${ }^{*} p<0.05,{ }^{* *} p<0.01,{ }^{* * *} p<0.001,{ }^{* * * *} p<0.0001$.

\subsection{Impact of Mo Treatment on Phenolic Level and Metabolism}

\subsubsection{Total Phenolic Content}

The impact of Mo on the total phenolic content of Canavalia species was evaluated. The total phenolic content was expressed as gallic acid equivalent (GAE). The results indicated that the production of phenols was increased significantly in CA3. A non-significant increase was observed in CA2, whereas a decrease was noticed in CA1, as given in Table 1. 
Table 1. Effect of molybdenum treatment on the nutritional value of Canavalia species/cultivar sprouts. Total lipids $(\mu \mathrm{g} / \mathrm{gFW})$, total proteins ( $\mu \mathrm{g} / \mathrm{gFW})$, fibers $(\mu \mathrm{g} / \mathrm{gFW})$, alkaloids $(\mu \mathrm{g} / \mathrm{gFW})$, phenolics $(\mu \mathrm{g} / \mathrm{gFW})$, flavanoids $(\mu \mathrm{g} / \mathrm{gFW})$, saponins $(\mu \mathrm{g} / \mathrm{gFW})$, and glycosides $(\mu \mathrm{g} / \mathrm{gFW})$ were measured. Experiments were executed in triplicate and the data are presented as mean \pm standard deviation (SD); Level of significance ${ }^{*} p<0.05$. Mo, Molybdenum.

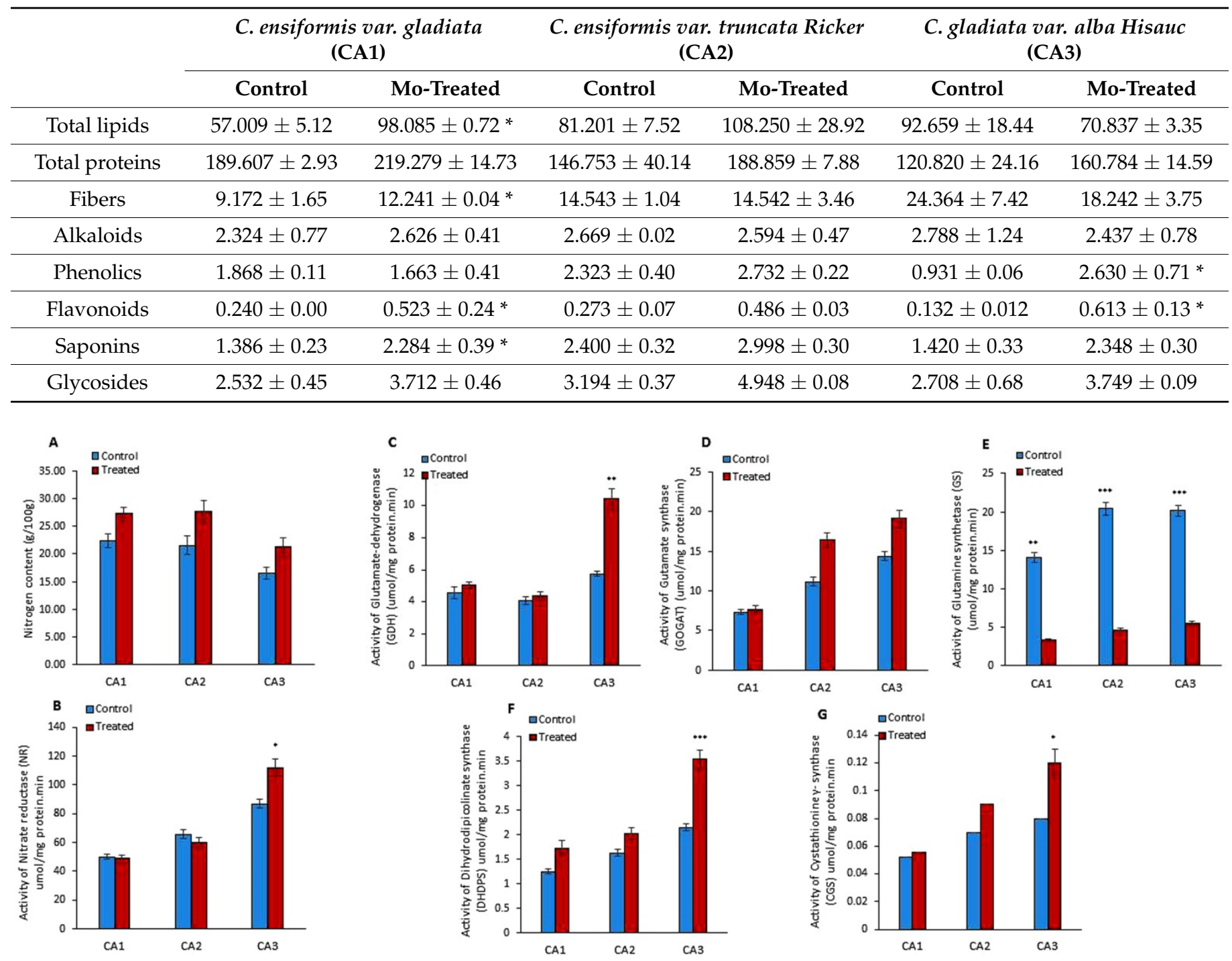

Figure 2. Effects of molybdenum (Mo) treatment on nitrogen assimilation. (A): Nitrogen (N) content (g/100gFW). (B): Nitrate reductase (umol/mg protein. $\mathrm{min}$ ) activity. (C): Glutamte dehydrogenase (GDH) activity ( $\mu \mathrm{mol} / \mathrm{mg}$ protein. $\mathrm{min}$ ). (D): Gutamate synthase (GOGAT) activity ( $\mu \mathrm{mol} / \mathrm{mg}$ protein. min). (E): Glutamine synthetase (GS) activity ( $\mu \mathrm{mol} / \mathrm{mg}$ protein. min). (F): Dihydrodipicolinate synthase (DHDPS) activity ( $\mu \mathrm{mol} / \mathrm{mg}$ protein. min). (G): Cystathionine $\gamma$ - synthase (CGS) activity ( $\mu \mathrm{mol} / \mathrm{mg}$ protein. $\mathrm{min})$. Control; without treatment, Treated; Mo treatment. CA1; Canavalia ensiformis var. gladiata, CA2; Canavalia ensiformis var. truncata Ricker, CA3; Canavalia gladiata var. alba Hisauc. Experiments were carried out in triplicate and the data are expressed as the mean \pm standard deviation; Level of significance ${ }^{*} p<0.05,{ }^{* *} p<0.01$, *** $p<0.001$. 
Table 2. Effect of molybdenum treatment on amino acid content ( $\mu \mathrm{mol} / \mathrm{gFW}$ ) of Canavalia species/cultivar sprouts. Experiments were carried out in triplicate and the data are expressed as mean \pm standard deviation (S.D); Level of significance, ${ }^{*} p<0.05 ;$ Mo, Molybdenum.

\begin{tabular}{|c|c|c|c|c|c|c|}
\hline & \multicolumn{2}{|c|}{$\begin{array}{l}\text { C. ensiformis var. gladiata } \\
\text { (CA1) }\end{array}$} & \multicolumn{2}{|c|}{$\begin{array}{c}\text { C. ensiformis var. truncata Ricker } \\
\text { (CA2) }\end{array}$} & \multicolumn{2}{|c|}{$\begin{array}{c}\text { C. gladiata var. alba Hisauc } \\
\text { (CA3) }\end{array}$} \\
\hline & Control & Mo-Treated & Control & Mo-Treated & Control & Mo-Treated \\
\hline Asparagine & $1.22 \pm 0.05$ & $1.41 \pm 0.06$ & $0.84 \pm 0.08^{*}$ & $1.261 \pm 0.03$ & $1.03 \pm 0.07$ & $1.7 \pm 0.11$ * \\
\hline Glutamine & $3.3 \pm 0.19$ & $3.98 \pm 0.37$ & $2.62 \pm 0.21$ & $5.060 \pm 0.4^{*}$ & $3.81 \pm 0.22$ & $6.29 \pm 0.55$ * \\
\hline Glutamic acid & $3.04 \pm 0.39$ & $2.42 \pm 0.93$ & $1.5 \pm 0.23$ & $4.040 \pm 0.2 *$ & $2.75 \pm 0.22$ & $4.92 \pm 0.65$ \\
\hline Serine & $0.8 \pm 0.03$ & $1.13 \pm 0.08$ & $0.89 \pm 0.05$ & $1.301 \pm 0.7$ & $1 \pm 0.06$ & $1.15 \pm 0.06$ \\
\hline Glycine & $0.46 \pm 0.01$ & $0.77 \pm 0.02 *$ & $0.6 \pm 0.03$ & $0.6 \pm 0.00$ & $0.58 \pm 0.05$ & $0.89 \pm 0.01 *$ \\
\hline Arginin & $0.25 \pm 0.01$ & $0.34 \pm 0.01$ & $0.3 \pm 0.01$ & $0.25 \pm 0.00$ & $0.32 \pm 0.02$ & $0.34 \pm 0.03$ \\
\hline Alanine & $0.49 \pm 0.17$ & $0.92 \pm 0.05 *$ & $0.49 \pm 0.22$ & $0.834 \pm 0.01 *$ & $1.5 \pm 0.59$ & $1.13 \pm 0.7$ \\
\hline Proline & $0.3 \pm 0.17$ & $0.67 \pm 0.13 *$ & $0.32 \pm 0.23$ & $0.698 \pm 0.03 *$ & $1.33 \pm 0.19$ & $0.96 \pm 0.04$ \\
\hline Histidine & $0.52 \pm 0.02$ & $0.71 \pm 0.07$ & $0.41 \pm 0.07$ & $0.366 \pm 0.08$ & $0.33 \pm 0.02$ & $0.58 \pm 0.05 *$ \\
\hline Valine & $0.48 \pm 0.03$ & $0.51 \pm 0.04$ & $0.29 \pm 0.05$ & $0.28 \pm 0.0$ & $0.30 \pm 0.03$ & $0.46 \pm 0.04$ \\
\hline Methionine & $0.4 \pm 0.01$ & $0.5 \pm 0.08$ & $0.41 \pm 0.01$ & $0.544 \pm 0.08$ & $0.42 \pm 0.02$ & $0.85 \pm 0.05 *$ \\
\hline Cystine & $0.32 \pm 0.08$ & $0.72 \pm 0.11$ * & $0.74 \pm 0.07$ & $0.944 \pm 0.1$ * & $0.65 \pm 0.08$ & $1.2 \pm 0.05^{*}$ \\
\hline Isoleucine & $0.41 \pm 0.08$ & $1.09 \pm 0.11 *$ & $0.72 \pm 0.03$ & $0.757 \pm 0.2$ & $0.64 \pm 0.06$ & $1.35 \pm 0.13$ * \\
\hline Leucine & $0.66 \pm 0.12$ & $1.44 \pm 0.14$ * & $0.75 \pm 0.11$ & $0.707 \pm 0.11$ & $1.21 \pm 0.11$ & $0.9 \pm 0.1$ \\
\hline Tyrosine & $0.33 \pm 0.01$ & $0.39 \pm 0.02$ & $0.3 \pm 0$ & $0.396 \pm 0.08$ & $0.28 \pm 0.01$ & $0.45 \pm 0.0$ * \\
\hline Lysine & $0.61 \pm 0.03$ & $1 \pm 0.2$ & $0.62 \pm 0.03$ & $1.075 \pm 0.05^{*}$ & $0.48 \pm 0.04$ & $0.91 \pm 0.04 *$ \\
\hline Threonine & $0.55 \pm 0.04$ & $0.71 \pm 0.02$ & $0.67 \pm 0.04$ & $0.76 \pm 0.01$ & $0.47 \pm 0.03$ & $0.77 \pm 0.01$ * \\
\hline Tryptophan & $0.2 \pm 0.01$ & $0.29 \pm 0.02$ & $0.21 \pm 0.01$ & $0.38 \pm 0.01$ * & $0.18 \pm 0.02$ & $0.4 \pm 0.02 *$ \\
\hline
\end{tabular}

\subsubsection{Phenolic Compounds}

Further, we evaluated the quantity of individual phenolic compounds in the Motreated group and compared them with untreated controls. Different phenols, i.e., gallic acid, caffeic acid, p-coumaric acid, chicoric acid, rosmarinic acid, protocatechuic acid, quercetin, naringenin, kaempferol, luteolin, apigenin, naringenin, rutin, and chlorogenic acid, were quantified using HPLC. The results revealed that Mo impacted the synthesis of different phenols in an interesting pattern among different species of Canavalia. Gallic acid, $p$-coumaric acid, rosmarinic acid, naringenin, and chlorogenic acid were enhanced significantly in CA1; caffeic acid, $p$-coumaric acid, chicoric acid, rosmarinic acid, naringenin, and apigenin were increased significantly in CA2; and gallic acid, chicoric acid, kaempferol, and chlorogenic acid were raised significantly in CA3. Enhanced production of caffeic acid, rosmarinic acid, and luteolin was observed in all three species after exposure to Mo. Interestingly, differential patterns were observed for other phenols (Table 3). Gallic and chlorogenic acid production was induced by Mo in CA1, while a reduction pattern was observed in CA2 and CA3. On the other hand, the biosynthesis of chicoric acid, protocatechuic acid, quercetin, and naringenin was decreased in CA1 and increased in CA2 and CA3. Moreover, $p$-coumaric acid and kaempferol were raised in CA1 and CA2 and reduced in CA3. Interestingly, apigenin synthesis was not affected by Mo treatment in CA2, while a reduction was found in CA2 and CA3-values are given in Table 3. 
Table 3. Effect of molybdenum treatment on phenolic compounds of Canavalia species/cultivar sprouts. Values are expressed as $\mu \mathrm{mol} / \mathrm{gFW}$. Experiments were performed in triplicate and the data are shown as mean \pm standard deviation (S.D); Asterisks $\left({ }^{*}\right)$ show the level of significance, ${ }^{*} p<0.05$; Mo, Molybdenum.

\begin{tabular}{ccccccc}
\hline & \multicolumn{2}{c}{$\begin{array}{c}\text { C. ensiformis var. gladiata } \\
\text { (CA1) }\end{array}$} & \multicolumn{2}{c}{$\begin{array}{c}\text { C. ensiformis var. truncata } \\
\text { Ricker (CA2) }\end{array}$} & \multicolumn{2}{c}{$\begin{array}{c}\text { C. gladiata var. alba Hisauc } \\
\text { (CA3) }\end{array}$} \\
\cline { 2 - 7 } & Control & Mo-Treated & Control & Mo-Treated & Control & Mo-Treated \\
\hline Gallic acid & $0.88 \pm 0.03$ & $1.44 \pm 0.1 *$ & $0.72 \pm 0.11$ & $0.58 \pm 0.1$ & $1.2 \pm 0.09$ & $0.63 \pm 0.22 *$ \\
\hline Caffeic acid & $1.71 \pm 0.3$ & $2.36 \pm 0.34$ & $1.782 \pm 0.38$ & $3.15 \pm 0.26^{*}$ & $3.218 \pm 0.18$ & $3.27 \pm 0.37$ \\
\hline p-Coumaric acid & $2.3 \pm 0.31$ & $3.44 \pm 0.41^{*}$ & $2.22 \pm 0.44$ & $3.32 \pm 0.27^{*}$ & $3.935 \pm 0.21$ & $3.42 \pm 0.22$ \\
\hline Chicoric acid & $0.79 \pm 0.03$ & $0.55 \pm 0.18$ & $0.83 \pm 0.04$ & $1.34 \pm 0.13^{*}$ & $0.93 \pm 0.07$ & $1.22 \pm 0.13 *$ \\
\hline Rosmarinic acid & $0.26 \pm 0.01$ & $0.37 \pm 0.03^{*}$ & $0.27 \pm 0.05$ & $0.41 \pm 0.02 *$ & $0.483 \pm 0.06$ & $0.48 \pm 0.03$ \\
\hline Protocatechuic acid & $1.52 \pm 0.21$ & $1.48 \pm 0.19$ & $1.53 \pm 0.1$ & $1.60 \pm 0.12$ & $2.24 \pm 0.28$ & $1.94 \pm 0.1$ \\
\hline Quercetin & $0.114 \pm 0.02$ & $0.14 \pm 0.03$ & $0.09 \pm 0.01$ & $0.105 \pm 0.02$ & $0.131 \pm 0.02$ & $0.141 \pm 0.02$ \\
\hline Naringenin & $0.15 \pm 0.01$ & $0.98 \pm 0.02$ & $0.78 \pm 0.01$ & $1.56 \pm 0.01 *$ & $1.58 \pm 0.01$ & $1.23 \pm 0.01$ \\
\hline Kaempferol & $0.72 \pm 0.02$ & $0.615 \pm 0.1$ & $1.10 \pm 0.16$ & $1.104 \pm 0.17$ & $1.094 \pm 0.11$ & $1.91 \pm 0.11 *$ \\
\hline Luteolin & $0.48 \pm 0.23$ & $0.34 \pm 0.22$ & $0.426 \pm 0.11$ & $0.42 \pm 0.18$ & $0.48 \pm 0.16$ & $0.40 \pm 0.2$ \\
\hline Apigenin & $0.35 \pm 0.12$ & $0.3 \pm 0.03$ & $0.004 \pm 0.03$ & $0.015 \pm 0.01 *$ & $0.017 \pm 0.03$ & $0.015 \pm 0.01$ \\
\hline Naringenin & $0.59 \pm 0.02$ & $1.272 \pm 0 *$ & $0.861 \pm 0.2$ & $0.97 \pm 0$ & $1.66 \pm 0$ & $1.87 \pm 0.1$ \\
\hline Rutin & $0.945 \pm 0$ & $1.10 \pm 0.014$ & $0.108 \pm 0.22$ & $0.104 \pm 0.08$ & $1.44 \pm 0.2$ & $1.47 \pm 0.28$ \\
\hline Chlorogenic acid & $0.08 \pm 0.06$ & $1.41 \pm 0.28 *$ & $0.84 \pm 0.45$ & $1.04 \pm 0.24$ & $1.04 \pm 0.36$ & $1.71 \pm 0.29 *$ \\
\hline
\end{tabular}

\subsubsection{Phenolic Metabolism}

Various parameters were determined to assess the endogenous metabolism of phenols in treated and untreated groups. For this purpose, the concentrations of phenylalanine, L-phenylalanine aminolyase, cinnamic acid, 3-deoxy-d-arabino heptulosonate-7-phosphate synthase (DAHPS), and shikimic acid were quantified (Figure 3). An inverse relation of DAHPS and shikimic acid was observed in the treated group of CA1 and CA2 (Figure 3A,B). The DAHPS activity was increased significantly in CA3, while it was decreased in CA1. A significant rise in the concentration of shikimic acid was observed in both CA2 and CA1. Phenylalanine was reduced in CA1, CA2, and CA3, but the change was not significant (Figure $3 \mathrm{C}$ ). In the case of L-phenylalanine aminolyase, we found that its activity was increased in CA2 and CA3, though decreased in CA1, after the application of Mo (Figure 3D). Cinnamic acid was decreased in CA1 and CA2, but in the third species an upward trend was observed upon Mo exposure. Cinnamic acid metabolism was not affected in CA3, while a decreasing pattern was found in CA1 and CA2 (Figure 3D). 

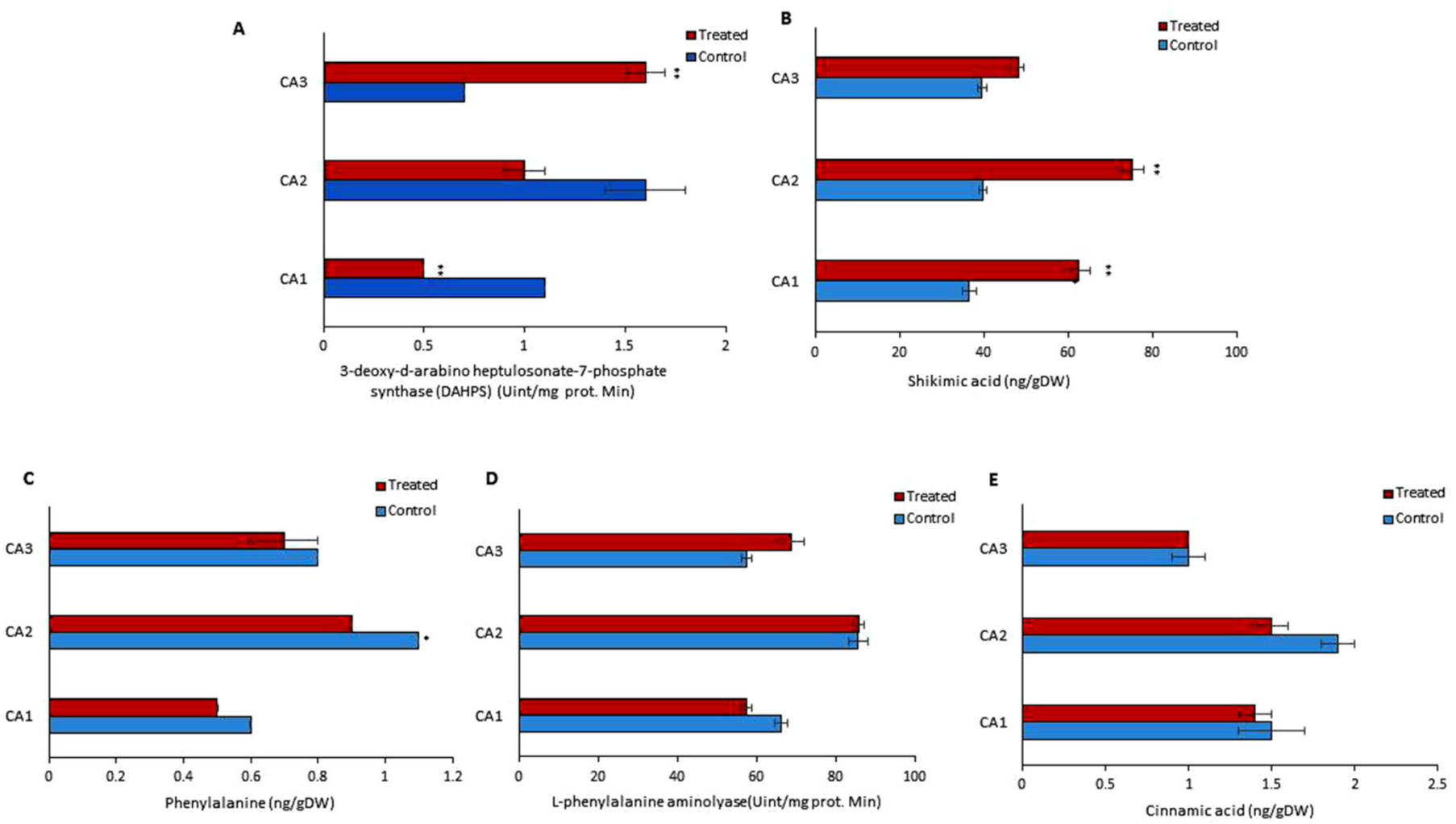

Figure 3. Effects of molybdenum (Mo) treatment on phenol synthesis pathway. (A): 3-deoxy-d-arabino heptulosonate-7phosphate synthase (DAHPS) activity. (B): Shikimic acid level. (C): Phenylalanine. (D): L-phenylalanine aminolyase activity. (E): Cinnamic acid content. Control; without treatment, Treated; Mo treatment. CA1; Canavalia ensiformis var. ladiate, CA2; Canavalia ensiformis var. ladiate Ricker, CA3; Canavalia ladiate var. alba Hisauc. The bars above mean indicate \pm standard deviation (S.D) of three independent replicates $(n=3)$. Asterisks $\left(^{*}\right)$ show the level of significance, ${ }^{*} p<0.05,{ }^{* *} p<0.01$.

\subsection{Impact of Mo Treatment on Biological Activity}

Figure 4 shows the antioxidant activity, quantified by the 2,2-diphenyl-1-picrylhydrazyl-hydrate (DPPH) free radical scavenging, 2,2-azino-bis(3-ethylbenzothiazoline-6sulfonic acid) (ABTS), ferric reducing antioxidant power (FRAP) methods, for the three plant species/cultivars of Canavalia after Mo exposure. The antioxidant activity, measured for each of the species, corresponds to an extract and Mo concentration. Regarding the antioxidant activity quantified by ABTS, the three species exhibited different antioxidant potentials, which was further increased after Mo exposure (Figure 4A). The antioxidant capacity pattern in controls was observed as CA1 > CA2 > CA3. Mo treatment induced a significant increase in CA3. Further, the values obtained from the FRAP assay also revealed the dramatic increase in antioxidant activity after Mo exposure, and a significant increase was recorded in both CA1 and CA3. Next, for the antioxidant activity quantified by DPPH, an increasing trend was obtained in all three species in the Mo-treated group, but the difference was non-significant. The glycemic index (GI), $\alpha$-amylase inhibition activity, and $\alpha$-glucosidase inhibition activity were assessed to explore the impact of Mo on the antidiabetic potential of Canavalia species. Through GI, a significant increase in antidiabetic potential was recorded in CA3, but in CA1 a decrease was noted. Further, the $\alpha$-amylase and $\alpha$-glucosidase inhibition potentials of Canavalia species were also increased. A-amylase inhibition was highly significant by CA2. A non-significant decrease was observed in CA3, as shown in Figure 4B. The evaluated percentage values of the inhibition of $\alpha$-glucosidase revealed that Mo positively enhanced the inhibition potential of the three species/cultivars of Canavalia. 
A

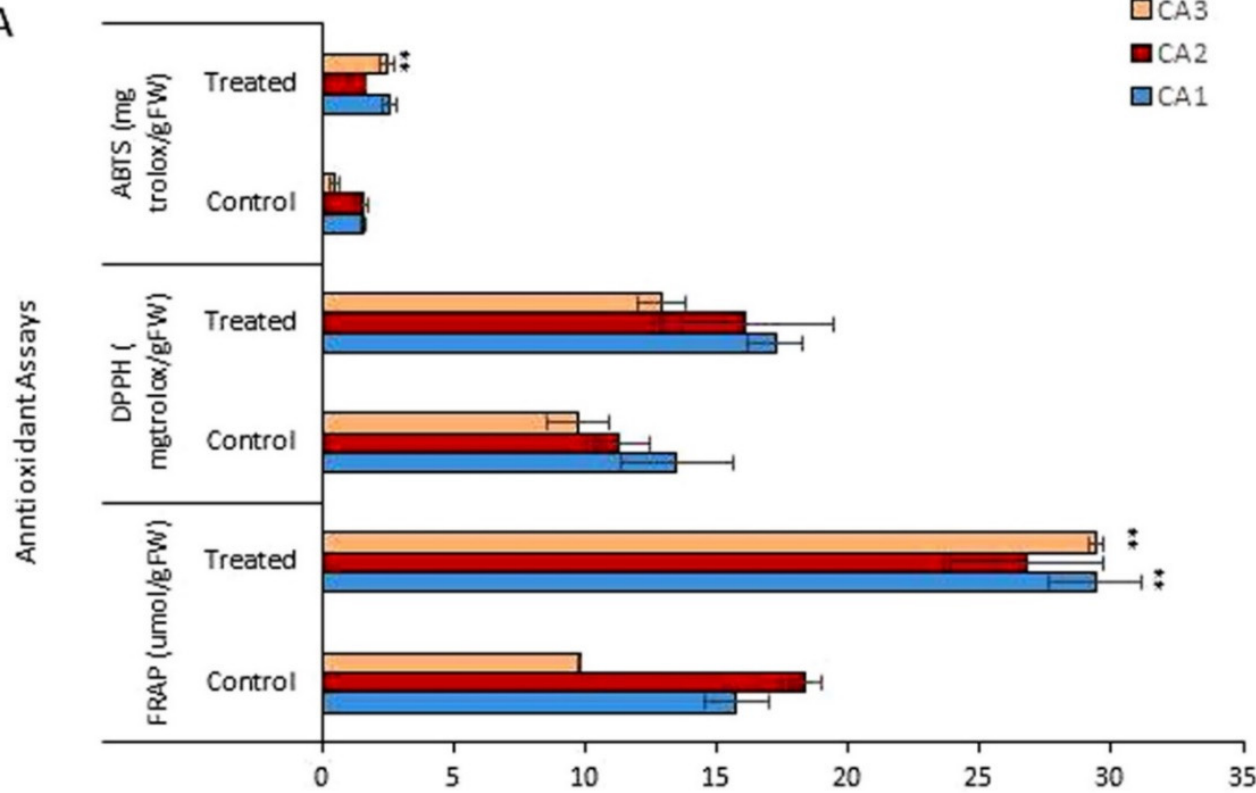

B

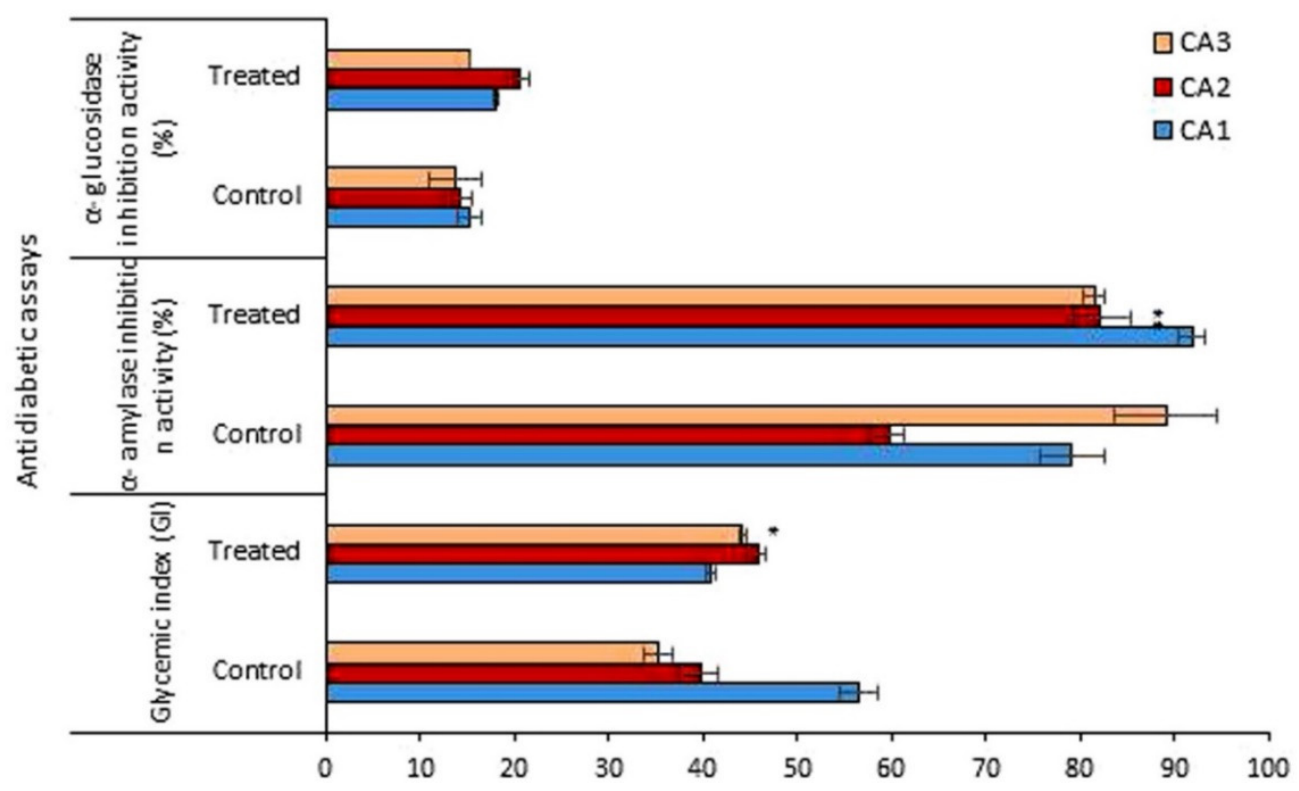

Figure 4. Effects of molybdenum (Mo) treatment on antioxidant and antidiabetic properties of Canavalia species (A): Antioxidant property, i.e., FRAP, ABTS, and DPPH. (B): Glycemic index (GI), $\alpha$-amylase inhibition activity, and $\alpha$-glucosidase inhibition activity. Control; without treatment, Treated; Mo treatment. CA; Canavalia ensiformis var. gladiata, CA2; Canavalia ensiformis var. truncata Ricker, CA3; Canavalia gladiata var. alba. The bars above means indicate \pm standard deviation (S.D) of three independent replicates $(n=3)$. Asterisks $\left(^{*}\right)$ show the level of significance according to analysis of variance (ANOVA), ${ }^{*} p<0.05,{ }^{* *} p<0.01$.

\subsection{Principle Component Analysis (PCA)}

$\mathrm{R}$ software was used to perform principal component analysis (PCA). For this, Motreated and untreated species of Canavalia were chosen to analyze the interrelationship of amino acid content, phenolics, antioxidant activities, and antidiabetic activities. Here, the 1st principal component (PC1) showed $36 \%$ of the variance, while the 2 nd principal component showed 28\% variance between untreated and Mo-treated Canavalia species, as shown in Figure 5. PC1 vs. PC2 showed significant differences among Mo-treated and 
untreated plant species as well as between CA1 and CA3. Both PCs displayed positive correlations among most of the parameters. PC1 was highly and positively correlated with many phenols, such as rutin, caffeic acid, kaempferol, rosmarinic acid, naringenin, and coumaric acid, etc., and amino acids including alanine, proline, cystine, and methionine, etc., whereas PC2 was positively related to histidine and valine. The results showed that all phenolic acids, as well as the total amount of phenols, differed with Mo treatment, whereas the treatments and species of Canavalia were well separated in the map of PCA. Moreover, the results of antioxidant activities also showed a positive correlation, assessed by ABTS and FRAP assays.

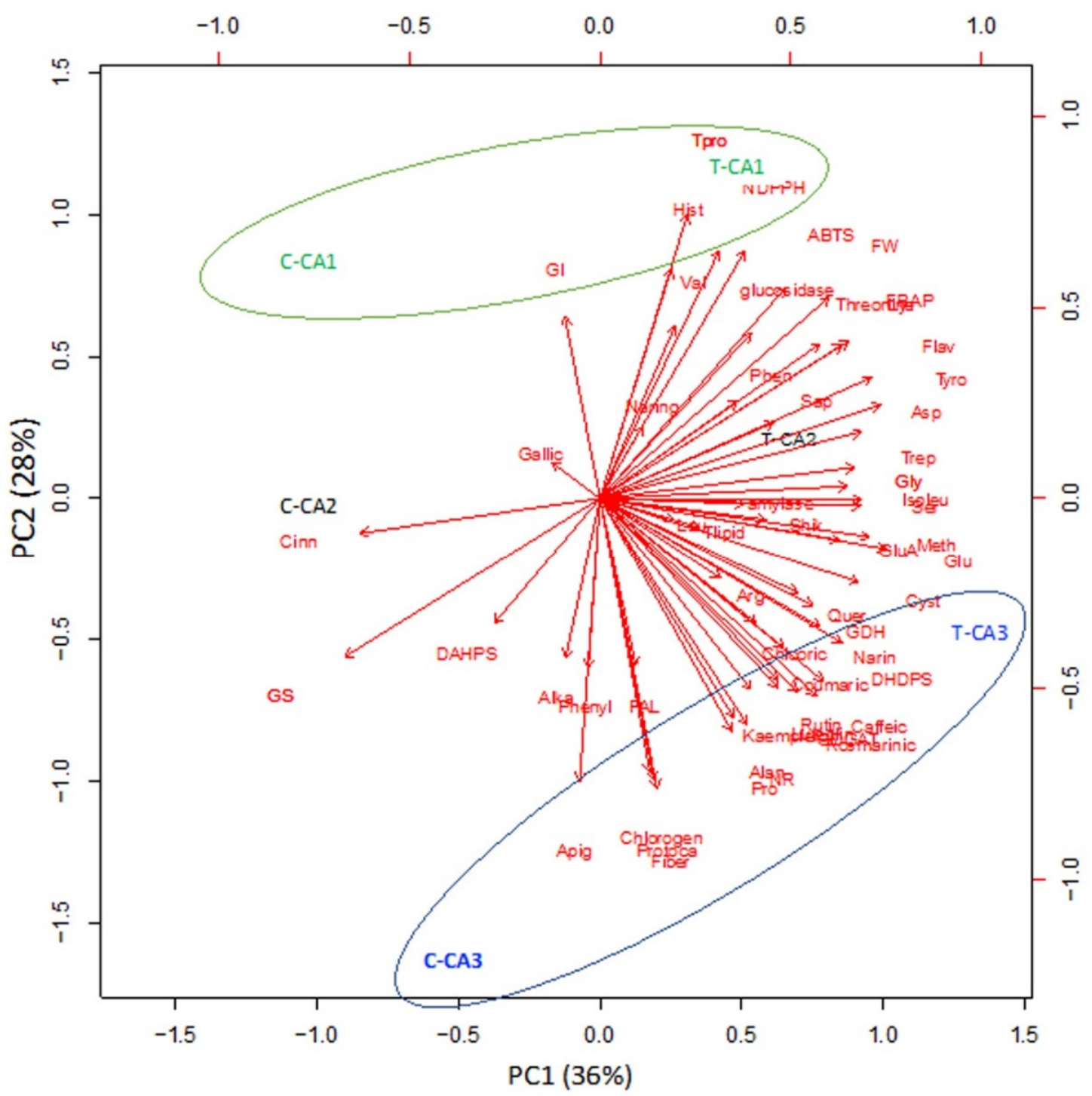

Figure 5. Principle component analysis (PCA) of 3 Canavalia species after seed priming with molybdenum (Mo). CA; Canavalia ensiformis var. gladiata, CA2; Canavalia ensiformis var. truncata Ricker, CA3; Canavalia gladiata var. alba Hisauc.

\section{Discussion}

The present study was conducted to explore the effects of seed priming using Mo on different endogenous chemical parameters of three species/cultivars of Canavalia. For this study, $0.1 \%$ ammonium molybdate was used and effects were monitored in sproutings of Canavalia ensiformis var. gladiata (CA1), Canavalia ensiformis var. truncata Ricker (CA2), and Canavalia gladiata var. alba Hisauc (CA3). We used the seed priming method as several studies indicated that seed treatment is a more efficient method for Mo than soil application $[20,21]$. Kumar Rao et al. reported that seed priming with Mo $\left(0.5 \mathrm{~g} \mathrm{~L}^{-1}\right.$ solution of 
sodium molybdite) increased the yield to $27 \%$, compared to Mo soil application, in a pot study on chickpea [22]. However, genetic variations led to interesting differential patterns among different species/cultivars in our study, which we have discussed. Similarly, the results also revealed that Mo has not targeted the biosynthetic pathways uniformly.

\subsection{Increased Canavalia Biomass Production by Improving Photosynthetic Pigments}

Micronutrients are crucial for plant growth and development. Their deficiency contributes to a reduction in growth and changes in photosynthesis due to variations in pigment synthesis. Increased chloroplast deformation, the over-production of antioxidant enzymes, and increased production of proteins are the most common signs of stress-related responses in plants. Mo, a micronutrient, acts as a cofactor for several enzymes, thus helping to promote plant growth and biomass [23], and its exposure can lead to dramatic effects on Canavalia species. In the current study, the biomass of sproutings, in both Mo-treated and untreated groups, was quantified. Our findings revealed that Mo treatment significantly increased the fresh weight of sproutings in all the studied Canavalia species/cultivars. Alam et al. also observed that Mo application proportionately enhanced the weight of nodules in hairy vetch roots [24]. This observation might be attributed to the fact that plants require micronutrients for biosynthetic pathways and plant growth [25].

Next, the impact of Mo on the photosynthesis process was assessed, for which pigments such as chlorophyll and carotenoids play an important role. Chlorophyll, which includes chlorophyll a, chlorophyll b, and chlorophyll ab, is a green pigment for photosynthesis. Carotenoids are also important pigments that exhibit antioxidant and provitamin A roles and are used extensively as natural and safe colorants for food and cosmetics [26]. In our study, exogenous Mo increased chlorophyll content in Canavalia. Indeed, Mo stabilizes the structure of chloroplasts, enhances the volume and number of chloroplast grana, and increases the synthesis of chlorophyll [27]. In agreement with the current results, it has been demonstrated that micronutrient Mo application enhanced chlorophyll content in Mung Bean (Vigna radiata L.) when its seeds were primed with Mo [28].

\subsection{Improved Nitrogen (N) Content and Amino Acid Metabolism}

Amino acids are the main part of the cellular structure. Their synthesis costs in terms of energy are expected to play an important role in energy allocation. It was experimentally shown that the source of nitrogen, predominantly nitrate and/or ammonium, affects amino acid and protein levels, as well as the rate of growth and, consequently, overall biomass [29]. Nitrogen assimilation by plants directly takes part in the synthesis and conversion of amino acids through the reduction of nitrate. In our study, Mo application improved $\mathrm{N}$ metabolism and as a result increased total protein content and amino acids in the Canavalia sprouts. Similar to our results, the study of Toledo et al. showed that Mo foliar application increased nitrogenase and nitrate reductase activities, which resulted in an increase in $\mathrm{N}$ accumulated in the soybean leaves [30]. Among the molybdo-enzymes, nitrate reductase (NR) represents the cytosolic key enzyme of nitrogen assimilation that reduces nitrate to nitrite [31]. We have observed that the Mo priming of seeds significantly increased NR expression in CA3, which is in line with the study of Camp et al. In that study, Mo treatment resulted in a rise in total grain $\mathrm{N}$ in soybean seeds [32]. Interestingly, this increase was not observed in the sprouting of CA1 and CA2, which might be due to different genetic backgrounds. Mechanistically, N production via Mo priming led to the modulation of many biochemical reactions of Canavalia species, which was observed in different experiments of the study. Normally, all $\mathrm{N}$ taken up by plants is first reduced to $\mathrm{NH} 4+$ because it is the only reduced $\mathrm{N}$ form available to plants for assimilation into $\mathrm{N}$-carrying amino acids [33]. Ammonium is then integrated into glutamine and glutamate. It was discovered that there are two pathways for glutamate synthesis. The glutamine synthetase (GS) / glutamate synthase (GOGAT) pathway is believed to assimilate ammonia at normal intracellular concentrations, while GDH (glutamate-dehydrogenase) plays a key role in the assimilation of ammonia into amino acids [34]. In our study, an increase 
in GDH and GOGAT production was detected in the three species, which was significant in CA3. GS production decreased in sprouts of the treated group and the change was significant in all three species/cultivars. The results are in line with the study of Imran et al., where Mo application up-regulated the expressions of GOGAT genes in winter wheat (Triticum aestivum L.) under a sole $\mathrm{NH}_{4}{ }^{+}$source [35,36]. Moreover, dihydrodipicolinate synthase (DHDPS) and cystathionine $\gamma$-synthase (CGS) are the first committed step in the biosynthesis of lysine and methionine, respectively, which occurs naturally in plants [37,38]. We observed an increase in the activity of DHDPS and CGS, which consequently increased the production of lysine and methionine in Mo-treated Canavalia species. The increase was significant in CA3, which might be due to the more prominent NR activity in CA3.

The amino acids in plants are not only essential components of protein synthesis, but also serve as precursors for a wide range of secondary metabolites that are important for plant growth as well as for human nutrition and health. The enhanced quantity of most of the amino acids in the study evidenced that there was an additional availability of amino acids, probably due to the greater biological fixation of $\mathrm{N}$ enhanced by Mo for the enzyme nitrogenase and the production of a greater quantity of ureides. Ureides are transported from the nodules to the aerial part and later converted into amino acids. The process resulted in a greater source of amino acids and, consequently, a higher protein content, as observed in our study. Conversely, Toledo et al. did not observe an increased protein content with applications of 30 and $60 \mathrm{~g} \mathrm{ha}^{-1}$ Mo applied by leaf spray or with $24 \mathrm{~g}$ $\mathrm{ha}^{-1}$ per seed treatment [30], which might be due to differences in species and/or different underlying biosynthetic mechanisms. Similar to our study, Oliveira et al. found a linear increase in the protein content of soybean when they applied doses of 0 to $800 \mathrm{~g} \mathrm{ha}^{-1} \mathrm{Mo}$ via foliar application [39]. In the current study, most of the amino acids were significantly increased in CA3 as compared to CA1 and CA2. This increase correlates to enhanced $\mathrm{N}$ metabolism and a significant increase in the biomass of CA3.

\subsection{Improved Nutritional Value}

Furthermore, the quantification of nutrients in sprouts showed a substantial increase in the lipid content of CA1, which might be due to increased synthesis and/or decreased degradation of lipids. Previous documents show that increased photosynthetic capacity due to Mo supply contributes to the accumulation of carbohydrates, such as fructose and glucose. We observed that lipids, fibers, and saponins were significantly increased in CA1. Flavonoids were increased reasonably in CA3. No significant change was observed in CA1 in all the studied parameters. Different impacts of Mo were observed in different species/cultivars, which might be due to different genetic backgrounds and the variable uptake of Mo.

\subsection{Secondary Phenolic Production Improvement as a Basis for High Bioactivity}

Phenolics play essential roles in plant development; these aromatic benzene ring compounds with one or more hydroxyl groups are produced by plants mainly for protection against stress [40]. In our study, the Mo priming of Canavalia seeds significantly increased the phenolic content of CA3 sprouts; a non-significant increase was found in CA2 and, surprisingly, a slight decrease was noticed in CA1. This might be due to differences in endogenous molecular pathways of different species. This link to the inherent levels of mechanisms may also lead to differences in the enhancing patterns of the individual phenolic compounds after Mo treatment, which we observed in our study. A similar trend was observed in DAHPS, the first enzyme of the shikimate pathway, which converts PEP and E4-P into 3-dehydroquaianate. Further, to assess the impact of Mo seed priming and enhanced phenolic production on the pharmacological properties of plants, we performed antioxidant and antidiabetic assays. FRAP, ABTS, and DPPH assays were used to evaluate the antioxidant capacity of species samples spectrophotometrically. An increase in antioxidant potential was observed after Mo treatment in all species. In the FRAP assay, the increase was significant in both CA1 and CA3. CA3 also expressed a significant change 
in antioxidant activity, measured via ABTS assay. This correlates to the above findings that more impacts of Mo on synthetic pathways were observed in CA3. Antioxidant activity has recently become a target for product development in the pharmaceutical and cosmetics industries [41]. Canavalia species are of medicinal importance due to their potential antioxidant properties. In a study, Canavalia gladiata extract, at the concentration of $2 \mathrm{mg} / \mathrm{mL}$, showed an antioxidant effect comparable to that of ascorbic acid of the control group [42]. Plant growth and antioxidant capacity are greatly dependent upon $\mathrm{N}$ availability. Higher $\mathrm{N}$ improves the stress tolerance of plants via enhancement of the antioxidant ability and inhibition of lipid peroxidation [43]. Mo primarily improves the nitrogen fixation to the plant and increases its antioxidant potential, which we observed in our study. This also might be the reason for the enhanced antidiabetic potential of Canavalia species assessed by GI, $\alpha$-amylase inhibition activity, and $\alpha$-glucosidase inhibition activity. Terpenoids and flavonoids of Canavalia gladiata are reported to play a role in lowering glucose levels and possessing antioxidant potential [44]. The Mo-mediated enhanced concentrations of terpenoids and flavonoids might have led to the increased antioxidant and antidiabetic activities of Canavalia sprouts in our study.

\section{Materials and Methods}

\subsection{Plant Material and Growth Conditions}

Seeds of three Canavalia species: Canavalia ensiformis var. gladiata (CA1), Canavalia ensiformis var. truncata Ricker (CA2), and Canavalia gladiata var. alba Hisauc (CA3), were collected from the Agricultural Research Center (Giza, Egypt). Healthy seeds with a similar shape and size were washed with distilled water and dripped for $1 \mathrm{~h}$ in $5 \mathrm{gL}^{-1}$ sodium hypochlorite, and then they were washed thoroughly with distilled water. According to a preliminary experiment, regarding the effect of ammonium molybdate (Mo) priming for $10 \mathrm{~h}$ at six concentrations, 0 (distilled water) and $0.025,0.05,0.075,0.1$, and $1.5 \%$ ammonium molybdate, $0.1 \%$ Mo-treated plants showed the highest biomass accumulation, thus $0.1 \%$ was selected to study the effect of Mo-priming on sprouts and tissue chemical composition of Canavalia species. About 250 seeds were primed for $10 \mathrm{~h}$ with distilled water or Mo $(0.1 \%)$ at room temperature $\left(24^{\circ} \mathrm{C}\right)$. For sprouting processes, the seeds were distributed on trays filled with vermiculite and irrigated with Milli-Q water every two days. Then, the seeds were evenly transferred to trays covered with vermiculite and moistened with $150 \mathrm{~mL}$ of aquaponic water (mineral-rich water that was collected from a catfish tank and adjusted to a target $\mathrm{pH}$ of 7). The growth conditions were $150 \mu \mathrm{mol}$ PAR m ${ }^{-2} \mathrm{~s}^{-1}$, $23 / 18.5^{\circ} \mathrm{C}$ air temperature, $63 \%$ humidity, and $16 / 8 \mathrm{~h}$ day/night photoperiod. The sprout tissues from each treatment were harvested after 9 days and weighed (Figure 6), then they were frozen in liquid nitrogen and kept at $-80^{\circ} \mathrm{C}$ for biochemical analyses. Each experiment was replicated at least two times, and for all assays, 3 to 5 replicates were used, and each replicate corresponded to a group of sprouts and mature plants harvested from a certain tray.

\subsection{Preparation of Extracts}

For sample preparation, we used an ETA 0067 grinder with grinding stones, VIPO mini grinder, followed by homogenization by Vibrom S2 (Jebavý, Trebechovice p. O., Czech Republic), and a cryogenic grinder accompanied by liquid nitrogen. Supercritical fluid extraction (SFE) using SE-1 (SeKo-K, Brno, Czech Republic) extractor and a steam distillatory apparatus according to CSN 580110 and CSN 6571 were successively applied for extraction and subsequent determination of the total content of Canavalia oils. Approximately $500 \mathrm{mg}$ of each sample was transferred into an extraction column for SFE extraction. The extraction was performed at $40 \mathrm{MPa}$ for $60 \mathrm{~min}$, and extractor and restrictor temperatures were 80 and $120^{\circ} \mathrm{C}$, respectively. The extract was further trapped into a hexane layer inside a trapping vessel. 


\section{Priming}

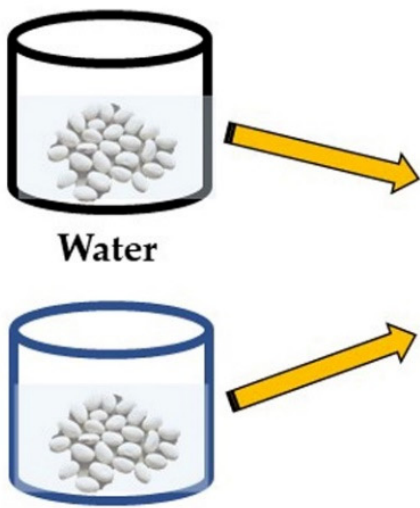

$0.1 \%$ Ammonium molybdate
Sprouting

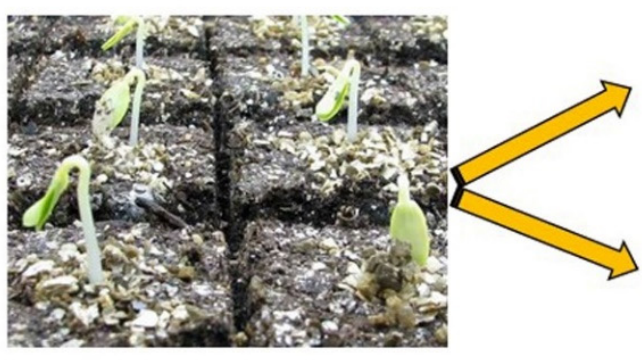

9 days
Harvesting

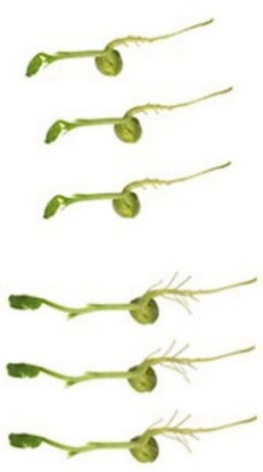

9 days old sprouts

Figure 6. Flow chart of the experimental design.

\subsection{Pigment Analysis}

To extract pigments, samples were homogenized in acetone and then centrifuged $\left(4{ }^{\circ} \mathrm{C}, 14,000 \times g, 20 \mathrm{~min}\right)$. HPLC (Shimadzu SIL10-ADvp, Tokyo, Japan, reversed-phase, at $4{ }^{\circ} \mathrm{C}$ ) was used to analyze the obtained solution (Almuhayawi et al., 2020). Carotenoids were separated (silica-based C18 column, Waters Spherisorb, $5 \mu \mathrm{m}$ ODS1, $4.6 \times 250 \mathrm{~mm}$ ), whereas they were eluted by (A) acetonitrile: methanol: water (81:9:10) and (B) methanol: ethyl acetate (68:32). The pigment was quantified using a diode-array detector (Shimadzu SPDM10Avp, Japan) at four wavelengths (420, 440, 462, and $660 \mathrm{~nm})$. Pigments were identified by comparing the standard mixture to the relative retention time of each pigment and the concentrations were calculated using the peak area of the corresponding standard.

\subsection{Determination of Nitrogen Content and Metabolism}

For total nitrogen $(\mathrm{N})$ content, fine ground sprout samples $(0.2 \mathrm{~g})$ were digested in $\mathrm{H}_{2} \mathrm{SO} 4-\mathrm{H}_{2} \mathrm{O}$ at $260^{\circ} \mathrm{C}$, and the nitrogen levels were assessed with a $\mathrm{CN}$ element analyzer (NC-2100, Carlo Erba Instruments, Milan, Italy). Glutamine synthetase (GS, EC 6.3.1.2), glutamate synthase (EC 1.4.7.1), and glutamine 2-oxoglutarate aminotransferase (GOGAT, EC 1.4.7.1) enzyme activities were measured by monitoring the reduction of NADH at $\mathrm{A}_{340}$. GDH determining 2-oxoglutarate-dependent NADH oxidation. GS activity was detected by assessing the formation of $\gamma$-glutamyl hydroxamate at A340. GOGAT activity was estimated by following the glutamine-dependent NADH oxidation at A340. The activity of the nitrate reductase (NR, EC 1.7.1.1) enzyme was measured by following the nitrite-dependent $\mathrm{NADH}$ oxidation $\left(\mathrm{A}_{340}\right)$ [45]. Protein concentrations were determined according to Lowry et al. [46].

\subsection{Amino Acid Analysis}

About $3 \mathrm{mg}$ of each Canavalia sample was hydrolyzed with $6 \mathrm{M} \mathrm{HCl}\left(6 \mathrm{~h}, 150{ }^{\circ} \mathrm{C}\right)$, and the acidic suspension was evaporated by rotary evaporation (RE500 Yamato Scientific America Inc., Santa Clara, CA, USA) and redissolved in $2 \mathrm{~mL}$ of sodium citrate buffer ( $\mathrm{pH}$ 2.2). For the derivation step, phthalaldehyde (OPA) $(7.5 \mathrm{mM})$ was mixed with samples in citrate buffer (OPA reagent containing $\beta$-mercaptoethanol and Brij 35). The HPLC (Shimadzu SPDM10Avp, Tokyo, Japan) analysis was evaluated using internal and external standards with the aid of fifteen amino acid reference standards $\left(0.05 \mu\right.$ moles $\mathrm{mL}^{-1}$ amino acid) for retention time detection of each single amino acid. In the meantime, the internal standard ( $0.05 \mu$ moles $\mathrm{mL}^{-1} \alpha$ aminobutyric) was added to both the plant sample and the reference. Reversed-phase C18 column (100 × $4.6 \mathrm{~mm} \times 1 / 4^{\prime \prime}$ Microsorb 100-3 C18, Agilent Technologies, Santa Clara, CA, USA) was used and gradient elution was performed by 
mobile phase consisting of $0.1 \mathrm{M}$ sodium acetate and methanol (9:1). Measurement was at a wavelength of 360 and $455 \mathrm{~nm}$. Star Chromatography software (Varian version 5.51) was applied for amino acid peak integration and final calculation was carried out to express values as $\mu \mathrm{mol} / \mathrm{gFW}$.

\subsection{Determination of Total Carbohydrates, Protein, Lipids, and Fibers}

Carbohydrate evaluation was processed for each Canavalia sample $\left(\mathrm{eCO}_{2}\right.$-treated and control plants) by Nelson's method [47], while the concentration of protein was measured for each frozen Canavalia sample (0.2 g FW). Detection of total lipids was performed using Folch's method [48], whereas the samples were subjected to homogenization in a chloroform/methanol mixture (2:1), followed by centrifugation at $3000 \times g$ for $15 \mathrm{~min}$ and concentration of chloroform extract containing lipids via a rotary evaporator (RE500 Yamato Scientific America Inc.); after that, the produced pellets were re-dissolved in a mixture of toluene/ethanol $(4 / 1 v / v)$ and then mixed with saline solution, re-concentrated again, and weighed to calculate the total lipid content $(\mu \mathrm{g} / \mathrm{gFW})$. Fibers were also extracted and evaluated according to the AOAC method [49], starting with sample gelatinization using $\alpha$-amylase $\left(30 \mathrm{~min}, \mathrm{pH} 6,100^{\circ} \mathrm{C}\right)$, then enzymatic digestion by protease $(30 \mathrm{~min}, \mathrm{pH}$ $7.5,60^{\circ} \mathrm{C}$ ). Thereafter, starch and proteins were removed by amyloglucosidase ( $30 \mathrm{~min}$, $\mathrm{pH} 6$ and $0{ }^{\circ} \mathrm{C}$ ). Finally, fibers were precipitated using ethanol, washed, and the yielded residue was weighed and expressed as $\mu \mathrm{g} / \mathrm{gFW}$.

\subsection{Determination of Phenolics and Their Precursors and Related Enzymes}

The determination of phenolics and their precursor metabolites was carried out using an ultra-performance liquid chromatography system (Waters Acquity UPLC, Boston, MA, USA) coupled with a quadrupole mass spectrometer (Waters Xevo TQ, Manchester, UK) provided with an ESI source according to Wang et al.'s method [50]. Phenolic and flavonoid levels were identified by comparing the standard mixture of different phenols and flavonoids to the relative retention time. The concentration of each compound $(\mu \mathrm{mol} / \mathrm{gFW})$ was calculated using the peak area of the corresponding standard.

In addition, deoxy-d-arabino 201 heptulosonate-7-phosphate synthase (DAHPS) activity (umol/mg protein. min) was analyzed according to Wang et al., (2020). This enzyme catalyzes the reactions in cinnamic and shikimic acid pathways that are involved in phenylpropanoid biogenesis and therefore in the biosynthesis of coumarins. Samples were first homogenized in $3 \mathrm{~mL} 50 \mathrm{mM}$ Tris-HCL buffer $(\mathrm{pH}=7.5)$. The assay mixture contained $0.1 \mathrm{mM}$ erythrose-4-phosphate, $0.2 \mathrm{mM}$ phosphoenolpyruvate, and $0.1 \mathrm{mM} \mathrm{MnSO} / 4 / 0.1 \mathrm{mM}$ $\mathrm{CoCl} 2$. In total, the reaction was initiated by enzyme addition and terminated by $25 \%(w / v)$ trichloroacetic acid addition. The activity of DAHPS was measured at $549 \mathrm{~nm}$. Regarding PAL, it was extracted in $1 \mathrm{~mL}$ of $200 \mathrm{mM}$ sodium borate buffer ( $\mathrm{pH} 8.8$ ) and then evaluated by measuring the production of trans-cinnamic acid at $290 \mathrm{~nm}$.

\subsection{Measurement of Antioxidant Capacity}

The determination of antioxidant activity was performed through ferric reducing antioxidant potential, 2,2-diphenyl-1-picryl-hydrazyl-hydrate (DPPH) free radical scavenging, 2,2-azino-bis(3-ethylbenzothiazoline-6-sulfonic acid) (ABTS), and ferric reducing antioxidant power (FRAP) assays according to the reported method [51]. In the FRAP method, about $0.2 \mathrm{~g}$ of Canavalia samples was firstly extracted in ethanol (80\%) and centrifuged at $14,000 \mathrm{rpm}$ for $20 \mathrm{~min}$. Afterward, $0.1 \mathrm{~mL}$ of tested extracts was added to $0.25 \mathrm{~mL}$ of FRAP reagent $\left(20 \mathrm{mM} \mathrm{FeCl}_{3}\right.$ in $0.25 \mathrm{M}$ acetate buffer, $\mathrm{pH}$ 3.6) at room temperature, the absorbance was further measured at $517 \mathrm{~nm}$, and antioxidant activity is expressed as $\mu \mathrm{mol} / \mathrm{gFW}$. In the DPPH assay, the reaction mixture was composed of $3.9 \mathrm{~mL}$ of $200 \mu \mathrm{M}$ DPPH (prepared in ethanol) and $0.1 \mathrm{~mL}$ of samples, incubated in the dark for half an hour at room temperature $\left(35 \pm 2{ }^{\circ} \mathrm{C}\right)$, and the absorbance was further detected at $517 \mathrm{~nm}$. The percentage of inhibition was calculated versus a control. ABTS (2,2' -azino-bis(3-ethylbenzothiazoline-6sulfonic acid) scavenging activity was measured by mixing ABTS with potassium persul- 
phate ( $2.4 \mathrm{mM})$, then the reaction was performed for 12 in the dark, and absorbance was measured at $734 \mathrm{~nm}$ and antioxidant activity was calculated as trolox/gFW.

\subsection{Anti-Diabetic Activity}

\subsubsection{Determination of In Vitro Glycemic Index (GI)}

In vitro starch hydrolysis assays were used for the evaluation of GI [52]. Sprouts were powdered and incubated with pepsin $(100 \mathrm{mg} / \mathrm{mL})$ in a reaction buffer $(\mathrm{HCl}-\mathrm{KCl}$ buffer, $\mathrm{pH}$ 1.5), incubated for $1 \mathrm{~h}$ at $40{ }^{\circ} \mathrm{C}$ with shaking, and then the mixture was diluted in phosphate buffer ( $\mathrm{pH}$ 6.9), adding $\alpha$-amylase and incubation at $37^{\circ} \mathrm{C}$. Approximately $1 \mathrm{~mL}$ of aliquots was taken every $30 \mathrm{~min}$ and boiled for $20 \mathrm{~min}$ for the sake of amylase enzyme inactivation. Residual starch was digested to glucose by adding $60 \mu \mathrm{L}$ amyloglucosidase together with $0.4 \mathrm{M}$ of sodium acetate buffer $(\mathrm{pH} 4.75)$, and the reaction mixture was previously incubated at $60^{\circ} \mathrm{C}$ for $50 \mathrm{~min}$. Aliquots $(0.6-\mathrm{mL})$ were incubated with $1.2 \mathrm{~mL}$ glucose oxidase/peroxidase at $37^{\circ} \mathrm{C}$ for $35 \mathrm{~min}$, followed by absorbance of the mixture at $500 \mathrm{~nm}$. Starch digestion rate (SDR) was evaluated as a hydrolyzed starch percentage at different times $(0,30,60,90,120$, and $180 \mathrm{~min})$. The area under the hydrolysis curve (AUC, $0-180 \mathrm{~min}$ ) was enumerated.

\subsection{2. $\alpha$-Glucosidase Inhibition Assay}

The percentage of $\alpha$-glucosidase inhibition activity was measured, as already reported [53]. The assay principle is about measuring the amount of para-nitrophenolate released by para-nitrophenyl glucopyranoside. The hydroethanolic extract of seeds and sprouts was mixed with $\alpha$-glucosidase $(2 \mathrm{U} / \mathrm{mL})$ and incubated at $37^{\circ} \mathrm{C}$ for $5 \mathrm{~min}$. Then, $1 \mathrm{mM}$ of para-nitrophenylglucopyranoside was added, dissolved in a phosphate buffer of $50 \mathrm{mM}$ ( $\mathrm{pH}$ 6.8) to the reaction buffer, and incubated for $20 \mathrm{~min}$ at $37^{\circ} \mathrm{C}$. The reaction was shut down by the addition of sodium carbonate (1M). The activity of $\alpha$-glucosidase was measured at $405 \mathrm{~nm}$. The percentage of inhibition was calculated.

\subsection{3. $\alpha$-Amylase Inhibition Assay}

$\alpha$-Amylase inhibition was evaluated by mixing starch $(2 \mathrm{mg})$ with $0.5 \mathrm{M}$ Tris- $\mathrm{HCl}$ buffer ( $\mathrm{pH}$ 6.9) and $0.01 \mathrm{M} \mathrm{CaCl} 2$, boiling for $5 \mathrm{~min}$, cooling at room temperature, and then incubating for $5 \mathrm{~min}$ at $37^{\circ} \mathrm{C}$. Then, the $\alpha$-amylase $(\mathrm{U} / \mathrm{mL})$ was added and incubated again at $37^{\circ} \mathrm{C}$ for $10 \mathrm{~min}$. After that, $500 \mu \mathrm{L} \mathrm{0.1 \%} \mathrm{3,5-dinitro} \mathrm{salicylic} \mathrm{acid} \mathrm{was} \mathrm{added} \mathrm{and}$ incubated for $10 \mathrm{~min}$ at $100^{\circ} \mathrm{C}$. After cooling, the absorbance was determined at $540 \mathrm{~nm}$ for $\alpha$-amylase inhibition calculation. The percentage of inhibition was calculated.

\subsection{Statistical Analyses}

The $p<0.05$ values were used to illustrate the statistical importance among the groups. The statistical analysis was conducted using both SPSS and MS Excel. Replication of each experiment was performed twice. Three to five replicates were used for all assays and each of the replicates corresponded to a group of control plants and Mo-treated plants. The PCA was carried out on R software.

\section{Conclusions}

The results demonstrated the benefits of Mo seed priming of three Canavalia species/cultivars to improve growth and N nutrition. Mo enrichment significantly triggered the photosynthetic pigments and enhanced the biomass of sprouts. In CA1, the lipids, fibers, flavonoids, and saponins were significantly increased, and in CA3 a significant rise was observed in phenolics and flavonoids. In CA3, higher differences were observed in $\mathrm{N}$ assimilation processes and amino acids as compared to CA1 and CA2, indicating that Mo-mediated impacts were greater in CA3. Further, Mo treatment affected the biosynthesis pathway of phenols, revealed by increased phenolic compounds in the sprouts. The raised levels of phenols and flavonoids were attributed to enhanced antioxidant acidity in CA1 and CA3. Differential patterns revealed that Mo-mediated impacts were not uniform in 
the Canavalia species/cultivars, which might be due to genetic variations and differential uptake. Overall, the findings from this research may facilitate a better understanding of the relationship of Mo application with yield and provide useful information for increasing the nutritional and pharmacological value of Canavalia species.

Author Contributions: Conceptualization, M.K.O. and H.A.; methodology, S.A.A., S.M.A.-Q.; software, N.A., A.A.A.-G., I.A.A. and H.A.; validation, M.K.O., A.I. and H.A.; formal analysis, Z.K.A., N.A. and S.S.; investigation, A.A.Q., W.H.S. and A.A.A.-G.; resources, M.K.O.; data curation, S.S., H.A. and N.A.; writing —original draft preparation, N.A.; writing—review and editing, N.A. and H.A. All authors have read and agreed to the published version of the manuscript.

Funding: This research was funded by a grant from the Research Group Program (RG-1439-63), King Saud University, Riyadh, Saudi Arabia.

Institutional Review Board Statement: Not applicable.

Informed Consent Statement: Not applicable.

Data Availability Statement: Data presented in this study are available on reasonable request.

Acknowledgments: The authors extend their appreciation to the Dean of Scientific Research, King Saud University for funding this work through the research group project number RG-1439-63. We also thank the Deanship of Scientific Research and RSSU at King Saud University for their support.

Conflicts of Interest: The authors declare no conflict of interest.

\section{References}

1. Michael, K.; Sogbesan, O.; Onyia, L. Effect of processing methods on the nutritional value of Canavalia ensiformis jack bean seed meal. J. Food Process. Technol. 2018, 9, 766.

2. Gebrelibanos, M.; Tesfaye, D.; Raghavendra, Y.; Sintayeyu, B. Nutritional and health implications of legumes. Int. J. Pharm. Sci. Res. 2013, 4, 1269.

3. Gulewicz, P.; Martínez-Villaluenga, C.; Frias, J.; Ciesiołka, D.; Gulewicz, K.; Vidal-Valverde, C. Effect of germination on the protein fraction composition of different lupin seeds. Food Chem. 2008, 107, 830-844. [CrossRef]

4. Yamashiro, A.; Yamashiro, T. Utilization on extrafloral nectaries and fruit domatia of Canavalia lineata and C. cathartica (Leguminosae) by ants. Arthropod-Plant Interact. 2008, 2, 1-8. [CrossRef]

5. Sridhar, K.R.; Seena, S. Nutritional and antinutritional significance of four unconventional legumes of the genus Canavalia-A comparative study. Food Chem. 2006, 99, 267-288. [CrossRef]

6. Jeon, K.S.; Na, H.J.; Kim, Y.M.; Kwon, H.J. Antiangiogenic activity of 4-O-methylgallic acid from Canavalia gladiata, a dietary legume. Biochem. Biophys. Res. Commun. 2005, 330, 1268-1274. [CrossRef] [PubMed]

7. Kim, O.K.; Chang, J.Y.; Nam, D.E.; Park, Y.K.; Jun, W.; Lee, J. Effect of Canavalia gladiata Extract Fermented with Aspergillus oryzae on the Development of Atopic Dermatitis in NC/Nga Mice. Int. Arch. Allergy Immunol. 2015, 168, 79-89. [CrossRef]

8. Byun, J.S.; Han, Y.S.; Lee, S.S. The effects of yellow soybean, black soybean, and sword bean on lipid levels and oxidative stress in ovariectomized rats. Int. J. Vitam. Nutr. Res. 2010, 80, 97-106. [CrossRef]

9. Han, S.S.; Hur, S.J.; Lee, S.K. A comparison of antioxidative and anti-inflammatory activities of sword beans and soybeans fermented with Bacillus subtilis. Food Funct. 2015, 6, 2736-2748. [CrossRef]

10. Lyu, Y.R.; Jung, S.-j.; Lee, S.-W.; Yang, W.-K.; Kim, S.-H.; Jung, I.C.; Kim, K.-H.; Kim, H.-Y.; Yang, Y.J.; Lee, Y.; et al. Efficacy and safety of CAEC (Canavalia gladiata arctium lappa extract complex) on immune function enhancement: An 8 week, randomised, double-blind, placebo-controlled clinical trial. J. Funct. Foods 2020, 75, 104259. [CrossRef]

11. Jashni, M.K.; Mehrabi, R.; Collemare, J.; Mesarich, C.H.; de Wit, P.J. The battle in the apoplast: Further insights into the roles of proteases and their inhibitors in plant-pathogen interactions. Front. Plant Sci. 2015, 6, 584. [CrossRef] [PubMed]

12. Mosolov, V.; Valueva, T. Participation of proteolytic enzymes in the interaction of plants with phytopathogenic microorganisms. Biochemistry 2006, 71, 838-845. [CrossRef]

13. Sowndhararajan, K.; Siddhuraju, P.; Manian, S. Antioxidant activity of the differentially processed seeds of Jack bean (Canavalia ensiformis L. DC). Food Sci. Biotechnol. 2011, 20, 585-591. [CrossRef]

14. Farooq, M.; Wahid, A.; Siddique, K.H. Micronutrient application through seed treatments: A review. J. Soil Sci. Plant Nutr. 2012, 12, 125-142. [CrossRef]

15. Matoso, S.C.; Kusdra, J.F. Nodulation and growth of bean in response to application of molybdenum and rhizobia inoculation. Rev. Bras. Eng. Agrícola Ambient. 2014, 18, 567-573. [CrossRef]

16. De Albuquerque, H.C.; Pegoraro, R.F.; Vieira, N.M.; de JesusFerreira Amorim, I.; Kondo, M.K. Nodulor capability and agronomic characteristics of common bean plants subjected to fragmented molybdenum and nitrogen fertilization. Rev. Ciência Agronômica 2012, 43, 214 . 
17. Mendel, R.R.; Hänsch, R. Molybdoenzymes and molybdenum cofactor in plants. J. Exp. Bot. 2002, 53, 1689-1698. [CrossRef]

18. Almeida, F.F.D.; Araújo, A.P.; Alves, B.J.R. Seeds with high molybdenum concentration improved growth and nitrogen acquisition of rhizobium-inoculated and nitrogen-fertilized common bean plants. Rev. Bras. Ciência Solo 2013, 37, 367-378. [CrossRef]

19. Hesberg, C.; Hänsch, R.; Mendel, R.R.; Bittner, F. Tandem orientation of duplicated xanthine dehydrogenase genes from Arabidopsis thaliana: Differential gene expression and enzyme activities. J. Biol. Chem. 2004, 279, 13547-13554. [CrossRef]

20. Donald, C.; Spencer, D. The control of molybdenum deficiency in subterranean clover by pre-soaking the seed in sodium molybdate solution. Aust. J. Agric. Res. 1951, 2, 295-301. [CrossRef]

21. Johansen, C.; Musa, A.M.; Kumar Rao, J.; Harris, D.; Yusuf Ali, M.; Shahidullah, A.; Lauren, J.G. Correcting molybdenum deficiency of chickpea in the High Barind Tract of Bangladesh. J. Plant Nutr. Soil Sci. 2007, 170, 752-761. [CrossRef]

22. Kumar Rao, J.; Harris, D.; Johansen, C.; Musa, A. Low cost provision of molybdenum (Mo) to chickpeas grown in acid soils. In Proceedings of the International Fertiliser Association Symposium on Micronutrients', New Delhi, India, 23-25 February 2004.

23. Hadi, F.; Ali, N.; Fuller, M.P. Molybdenum (Mo) increases endogenous phenolics, proline and photosynthetic pigments and the phytoremediation potential of the industrially important plant Ricinus communis L. for removal of cadmium from contaminated soil. Environ. Sci. Pollut. Res. 2016, 23, 20408-20430. [CrossRef] [PubMed]

24. Alam, F.; Kim, T.Y.; Kim, S.Y.; Alam, S.S.; Pramanik, P.; Kim, P.J.; Lee, Y.B. Effect of molybdenum on nodulation, plant yield and nitrogen uptake in hairy vetch (Vicia villosa Roth). Soil Sci. Plant Nutr. 2015, 61, 664-675. [CrossRef]

25. Gungula, D.; Garjila, Y. The effects of molybdenum application on growth and yield of cowpea in Yola. J. Agric. Environ. Sci. 2006, 1, 96-101.

26. Zakynthinos, G.; Varzakas, T. Carotenoids: From plants to food industry. Curr. Res. Nutr. Food Sci. 2016, 4, 38. [CrossRef]

27. Han, Z.; Wei, X.; Wan, D.; He, W.; Wang, X.; Xiong, Y. Effect of molybdenum on plant physiology and cadmium uptake and translocation in rape (Brassica napus 1.) Under different levels of cadmium stress. Int. J. Environ. Res. Public Health 2020, 17, 2355. [CrossRef]

28. Hayyawi, N.J.H.; Al-Issawi, M.H.; Alrajhi, A.A.; Al-Shmgani, H.; Rihan, H. Molybdenum Induces Growth, Yield, and Defence System Mechanisms of the Mung Bean (Vigna radiata L.) under Water Stress Conditions. Int. J. Agron. 2020, $2020,8887329$. [CrossRef]

29. Helali, S.M.r.; Nebli, H.; Kaddour, R.; Mahmoudi, H.; Lachaâl, M.; Ouerghi, Z. Influence of nitrate-Ammonium ratio on growth and nutrition of Arabidopsis thaliana. Plant Soil 2010, 336, 65-74. [CrossRef]

30. Toledo, M.Z.; Garcia, R.A.; Rocha Pereira, M.R.; Fernandes Boaro, C.S.; Lima, G.P.P. Nodulação e atividade da nitrato redutase em função da aplicação de molibdênio em soja. Biosci. J. 2010, 26, 858-864.

31. Campbell, W.H. Structure and function of eukaryotic NAD(P)H:nitrate reductase. Cell. Mol. Life Sci. CMLS 2001, 58, 194-204. [CrossRef]

32. Campo, R.J.; Araujo, R.S.; Hungria, M. Molybdenum-enriched soybean seeds enhance N accumulation, seed yield, and seed protein content in Brazil. Field Crop. Res. 2009, 110, 219-224. [CrossRef]

33. Ruiz, J.M.; Rivero, R.M.; Romero, L. Comparative effect of Al, Se, and Mo toxicity on NO3(-) assimilation in sunflower (Helianthus annuus L.) plants. J. Environ. Manag. 2007, 83, 207-212. [CrossRef]

34. Cammaerts, D.; Jacobs, M. A study of the role of glutamate dehydrogenase in the nitrogen metabolism of Arabidopsis thaliana. Planta 1985, 163, 517-526. [CrossRef] [PubMed]

35. Imran, M.; Sun, X.; Hussain, S. Molybdenum-induced effects on nitrogen metabolism enzymes and elemental profile of winter wheat (Triticum aestivum L.) under different nitrogen sources. Int. J. Mol. Sci. 2019, 20, 3009. [CrossRef] [PubMed]

36. Bataung, M.; Xianjin, Z.; Guozheng, Y.; Xianlong, Z. Review: Nitrogen assimilation in crop plants and its affecting factors. Can. J. Plant Sci. 2012, 92, 399-405. [CrossRef]

37. Pearce, F.G.; Hudson, A.O.; Loomes, K.; Dobson, R.C. Dihydrodipicolinate synthase: Structure, dynamics, function, and evolution. Subcell Biochem. 2017, 83, 271-289.

38. Ravanel, S.; Gakière, B.; Job, D.; Douce, R. The specific features of methionine biosynthesis and metabolism in plants. Proc. Natl. Acad. Sci. USA 1998, 95, 7805-7812. [CrossRef]

39. Oliveira e Oliveira, C.; Cipriano Pinto, C.; Garcia, A.; Trombeta Bettiol, J.V.; de Sá, M.E.; Lazarini, E. Produção de sementes de soja enriquecidas com molibdênio. Rev. Ceres 2017, 64. [CrossRef]

40. Bhattacharya, A.; Sood, P.; Citovsky, V. The roles of plant phenolics in defence and communication during Agrobacterium and Rhizobium infection. Mol. Plant Pathol. 2010, 11, 705-719. [CrossRef]

41. Żymańczyk-Duda, E.; Szmigiel-Merena, B.; Brzezińska-Rodak, M. Natural antioxidants-properties and possible applications. J. Appl. Biotechnol. Bioeng. 2018, 5, 251-258. [CrossRef]

42. Kim, H.C.; Moon, H.G.; Jeong, Y.C.; Park, J.U.; Kim, Y.R. Anti-oxidant, skin whitening, and antibacterial effects of Canavalia gladiata extracts. Med. Biol. Sci. Eng. 2018, 1, 11-17. [CrossRef]

43. Fu, J.; Huang, B. Effects of foliar application of nutrients on heat tolerance of creeping bentgrass. J. Plant Nutr. 2003, 26, 81-96. [CrossRef]

44. Anitha, K.; Lakshmi, S.M.; Satyanarayana, S. Antidiabetic, lipid lowering and antioxidant potentiating effect of Canavalia species in high fat diet-streptozotocin induced model. Adv. Tradit. Med. 2020, 20, 609-618. [CrossRef]

45. Hageman, R.; Reed, A. [24] Nitrate reductase from higher plants. In Methods in Enzymology; Elsevier: Amsterdam, The Netherlands, 1980; Volume 69. 
46. Classics Lowry, O.; Rosebrough, N.; Farr, A.; Randall, R. Protein measurement with the Folin phenol reagent. J. Biol. Chem. 1951, 193, 265-275. [CrossRef]

47. Clark, R.A.; Delia, J.G. Cognitive complexity, social perspective-taking, and functional persuasive skills in second-to ninth-grade children. Hum. Commun. Res. 1977, 3, 128-134. [CrossRef]

48. Bligh, E.G.; Dyer, W.J. A rapid method of total lipid extraction and purification. Can. J. Biochem. Physiol. 1959, 37, 911-917. [CrossRef]

49. Horwitz, W.; Chichilo, P.; Reynolds, H. Official methods of analysis of the Association of Official Analytical Chemists. In Official Methods of Analysis of the Association of Official Analytical Chemists; Association of Official Analytical Chemists: Washington, DC, USA, 1970.

50. Wang, Z.; Xiao, S.; Wang, Y.; Liu, J.; Ma, H.; Wang, Y.; Tian, Y.; Hou, W. Effects of light irradiation on essential oil biosynthesis in the medicinal plant Asarum heterotropoides Fr. Schmidt var. mandshuricum (Maxim) Kitag. PLoS ONE 2020, 15, e0237952. [CrossRef] [PubMed]

51. Almuhayawi, M.S.; Hassan, A.H.; Al Jaouni, S.K.; Alkhalifah, D.H.M.; Hozzein, W.N.; Selim, S.; AbdElgawad, H.; Khamis, G. Influence of elevated $\mathrm{CO}_{2}$ on nutritive value and health-promoting prospective of three genotypes of Alfalfa sprouts (Medicago sativa). Food Chem. 2021, 340, 128147. [CrossRef]

52. Hasan, M.; Hanafiah, M.M.; Aeyad Taha, Z.; AlHilfy, I.H.; Said, M.N.M. Laser irradiation effects at different wavelengths on phenology and yield components of pretreated maize seed. Appl. Sci. 2020, 10, 1189. [CrossRef]

53. Kazeem, M.; Adamson, J.; Ogunwande, I. Modes of inhibition of $\alpha$-amylase and $\alpha$-glucosidase by aqueous extract of Morinda lucida Benth leaf. BioMed Res. Int. 2013, 2013, 527570. [CrossRef] 